\title{
Pengaruh Pendapatan Bagi Hasil dan Pemberian Bonus terhadap Loyalitas Nasabah di Bank Syariah Mandiri Kantor Cabang Sangatta
}

\author{
Khairi \\ Sekolah Tinggi Agama Islam Sangatta \\ E-mail : khairimartapura@gmail.com \\ Eko Nursalim \\ Sekolah Tinggi Agama Islam Sangatta \\ E-mail : ekonursalim@gmail.com \\ Parno \\ Institut Agama Islam Negeri Samarinda \\ E-mail :agt122005@gmail.com
}

\begin{abstract}
This type of research is descriptive quantitative. This study uses analytical techniques that include path analysis with the aim to find out the direct and indirect influence of independent variables on the dependent variables processing data using SPSS, simultaneous testing (F test) and individual testing ( $t$ test). The population in this study are customers in Bank Syariah Mandiri Sangatta Branch Office. And the number of samples taken by 98 respondents by using random sampling technique. The results showed that there is a significant influence between income sharing (X1) and bonus (X2) to customer loyalty $(Y)$ either partially or simultaneously. From the results if the data is known value of correlation coefficient $(R)$ of 0,542 with interpretation between 0,40 - 0,599 which means existence of positive relation between variable of revenue sharing and giving bonus to customer loyalty, and included in category strong enough. The results of this study indicate that the revenue-sharing variable and bonus giving contributes to customer loyalty variables with a total influence of $29.4 \%$ and the remaining $70.6 \%$ is likely determined by other factors and not examined in this study. And the path equation is $Y=0,366 X 1+0,297 X 2$.
\end{abstract}

Keywords: Profit Sharing, Bonus Giving, Customer Loyalty. 


\begin{abstract}
ABSTRAK
Jenis penelitian ini adalah deskriptif kuantitatif. Studi ini menggunakan teknik analitis yang mencakup analisis jalur dengan tujuan untuk mengetahui pengaruh langsung dan tidak langsung pada variabel independen dengan variabel dependen. Pengolahan data menggunakan SPSS. Teknik analisis menggunakan uji F (uji simultan) dan uji (uji parsial). Responden dalam penelitian ini adalah nasabah Bank Syariah Mandiri Kantor Cabang Sangatta, Jumlah sampel yang diambil adalah 98 responden dengan menggunakan teknik random sampling. Hasil analisis menunjukkan terdapat pengaruh yang signifikan antara penerimaan bagi hasil (x1) dan penerimaan bonus (x2) terhadap loyalitas pelanggan (y) baik parsial atau secara simultan. Dari hasil analisis data diperoleh nilai koefisien korelasi (r) 0,542 dengan interpretasi antara 0,40 - 0,599 yang berarti menunjukkan hubungan yang positif antara pembagian bagi hasil, pemberian bonus dan loyalitas nasabah, dan termasuk dalam kategori cukup kuat. Hasil analisis menunjukkan bahwa variabel pemberian bagi hasil (x1) dan pemberian bonus (x2) berpengaruh sebesar 29,5\% terhadap loyalitas nasabah $(y)$, sisanya $(70,6 \%)$ dipengaruhi oleh faktor lain yang tidak diteliti dalam penelitian ini.
\end{abstract}

Kata Kunci : Bagi Hasil, Pemberian Bonus, Loyalitas Nasabah.

\title{
Pendahuluan
}

Perbankan adalah suatu lembaga keuangan yang paling penting dan besar peranannya dalam kehidupan masyarakat. Lembaga keuangan bank dalam arti luas adalah sebagai perantara dari pihak yang mempunyai kelebihan dana (surplus of funds) dengan pihak yang kekurangan dana (lack of funds) sehingga peranan dari lembaga keuangan bank yang sebenarnya, yaitu sebagai perantara keuangan masyarakat (financial intermediary) (Djumhana 2006, 101). Perbankan di Indonesia memiliki dua sistem perbankan yaitu perbankan konvensional yang menggunakan sistem bunga dan perbankan syariah yang menggunakan sistem bagi hasil sesuai dengan prinsip syariat Islam.

Pada prinsipnya bank konvensional dan bank syariah mempunyai kesamaan yaitu lembaga keuangan yang bertujuan untuk menghimpun dana dari masyarakat dan menyalurkan dana kepada masyarakat. Namun dalam operasionalnya bank konvensional menjalankannya dengan imbalan bunga, sedangkan pada bank syariah tidak terpengaruh oleh 
tingkat rate bunga akan tetapi dalam operasionalnya berdasarkan pada prinsip bagi hasil yang bebas bunga. Menurut Schaik sebagaimana dikutip oleh Buchari dan Donni, bank syariah adalah sebuah bentuk dari bank modern yang didasarkan pada hukum Islam yang sah, dikembangkan pada abad pertama Islam, menggunakan konsep berbagi risiko sebagai metode utama, dan meniadakan keuangan berdasarkan kepastian serta keuntungan yang ditentukan sebelumnya (Antonio 2001, 26).

Eksistensi perbankan syariah saat ini menempati posisi yang strategis dalam menjembatani kebutuhan modal kerja dan investasi di sektor riil dengan pemilik dana atau sebagai penyedia jasa tempat menyimpan kekayaan. Dengan adanya perbankan syariah diharapkan masyarakat dapat berinvestasi dan bermuamalah sesuai dengan syariah, karena dalam hal ini banyak sekali bentuk investasi yang ternyata tidak sesuai dengan prinsip syariah Islam.

Salah satu bank milik pemerintah pertama yang melandaskan operasionalnya pada prinsip syariah yaitu Bank Syariah Mandiri (BSM). Secara struktural, BSM berasal dari Bank Susila Bakti (BSB), sebagai salah satu anak perusahaan di lingkup Bank Mandiri (ex BDN), yang kemudian dikonversikan menjadi bank syariah secara penuh. Dalam rangka melancarkan proses konversi menjadi bank syariah, BSM menjalin kerjasama dengan Tazkia Institute, terutama dalam bidang pelatihan dan pendampingan konversi (Alma and Priansa 2009, 7).

Seperti halnya bank konvensional, bank syariah juga memiliki produk-produk serta jasa perbankan yang dapat dinikmati dan dimanfaatkan oleh masyarakat umum. Produk perbankan syariah tersebut secara garis besar dapat dibedakan menjadi 3 jenis produk, yaitu produk penghimpunan dana, produk penyaluran dana dan produk jasa perbankan. Bank Syariah Mandiri merupakan salah satu bank syariah terbesar di Indonesia. Bank Syariah Mandiri saat ini sudah memiliki beraneka macam produk unggulan, baik berupa penghimpunan dana, penyaluran dana maupun jasa perbankan. Seluruh produk dari Bank Syariah Mandiri terjamin dari praktik riba, karena seluruh akadnya jelas dan sesuai dengan prinsip-prinsip syariah salah satunya yaitu dengan menggunakan akad mudharabah dan akad wadiah. 
Menurut Ahmad asy-Syarbasyi sebagaimana dikutip oleh Syafi'i Antonio, mudharabah adalah akad kerjasama usaha antara dua pihak dimana pihak pertama (shahibul maal) menyediakan seluruh modal, sedangkan pihak lainnya menjadi pengelola. Keuntungan usaha dibagi menurut kesepakatan dalam kontrak, sehingga apabila terjadi kerugian ditanggung oleh pemilik modal selama kerugian itu bukan akibat kelalaian si pengelola. Seandainya kerugian itu diakibatkan karena kecurangan atau kelalaian pengelola, pengelola harus bertanggung jawab atas kerugian tersebut (Antonio 2001, 95).

Dalam hal ini Bank Syariah Mandiri menerapkan prinsip bagi hasil. Bagi hasil yaitu sistem yang meliputi tata cara pembagian hasil usaha antara penyedia dana dengan pengelola dana. Penentuan bagi hasil berdasarkan profit sharing maupun revenue sharing ditentukan dengan nisbah yang disepakati. Nisbah merupakan faktor penting dalam menentukan bagi hasil yang disepakati bersama antara kedua belah pihak yang melakukan transaksi pada bank syariah (Karim 2011, 345). Adapun pengertian nisbah adalah besaran yang digunakan untuk pembagian keuntungan, mencerminkan imbalan yang berhak diterima oleh kedua pihak yang bermudharabah atas keuntungan yang diperoleh. Nisbah keuntungan harus diketahui dengan jelas oleh kedua pihak, inilah yang akan mencegah terjadinya perselisihan antara kedua belah pihak mengenai cara pembagian keuntungan. Selain menggunakan prinsip bagi hasil, Bank Syariah Mandiri juga menggunakan akad wadi'ah yang penarikannya dapat dilakukan setiap saat berdasarkan syarat-syarat yang disepakati.

Menurut Adiwarman Karim, tabungan wadiah merupakan tabungan yang dijalankan berdasarkan akad wadi'ah, yakni titipan murni yang harus dijaga dan dikembalikan setiap saat sesuai dengan kehendak pemiliknya. Berkaitan dengan produk tabungan wadiah, bank syariah menggunakan akad wadiah yad adh-dhamanah (Karim 2011, 345). Tabungan wadiah dengan akad wadi'ah yad adh-dhamanah adalah jasa penitipan dana dalam hal ini penitip atau nasabah dapat mengambil dana tersebut sewaktu-waktu. Dengan sistem wadi'ah bank dibolehkan memberikan bonus kepada nasabah sebagai bentuk kompensasi kepada nasabah atas kepercayaan nasabah menabung di bank tersebut. Saat ini 
produk tabungan wadiah mulai mendapat perhatian dari masyarakat. Tabungan wadi'ah ini menarik karena merupakan salah satu bentuk produk tabungan perbankan syariah yang memberikan rasa aman. Dalam hal ini dana simpanan nasabah tidak mungkin berkurang, bahkan bisa bertambah dari saldo awal pada jangka waktu tertentu. Penambahan saldo tersebut berasal dari bonus yang diberikan oleh pihak bank. Bonus yang diberikan tersebut tidak boleh diperjanjikan di awal, dan murni kebijakan bank semata yang bersifat sukarela (Karim 2011, 345). Dengan adanya bonus yang diberikan maka diharapkan masyarakat tertarik untuk menyimpan dananya di Bank Syariah khususnya di Bank Syariah Mandiri KC Sangatta.

Dengan adanya pendapatan keuntungan dari bagi hasil dan pemberian bonus dari pihak bank, maka loyalitas nasabah menjadi sangat penting. Sebagaimana diketahui tujuan dari suatu bisnis adalah untuk menciptakan para pelanggan merasa puas. Terciptanya kepuasan dapat memberikan beberapa manfaat, diantaranya hubungan antara perusahaan dengan pelanggannya menjadi harmonis sehingga memberikan dasar yang baik bagi pembelian ulang dan terciptanya kesetiaan terhadap produk serta rekomendasi dari mulut ke mulut (word of mouth) yang menguntungkan perusahaan (Tjiptono 2015, 106).

Menurut Lewis P. Carbone sebagaimana dikutip oleh Rismi dan Donni, pelanggan merupakan aset yang sangat penting karena tidak ada satupun organisasi bisnis yang akan mampu bertahan bila ditinggalkan oleh pelanggannya. Pelanggan adalah yang paling berpengaruh terhadap nilai organisasi dalam menjalankan bisnisnya, bukan Chief Executive Officer (CEO), Chief Financial Officer (CFO), shareholder atau stakeholder. Bahkan $80 \%$ penghasilan organisasi bisnis ditentukan oleh pelanggan yang loyal, sementara $20 \%$ lainnya ditentukan oleh pelanggan yang cobacoba atau temporer (Somad and Priansa 2014, 28). Loyalitas pelanggan merupakan bentuk kesetiaan seseorang serta perilaku seseorang untuk mau dan bersedia merekomendasikan apa yang ia rasakan kepada orang lain adalah bentuk dari kecintaan dan kepercayaan pelanggan terhadap suatu perusahaan. Loyalitas adalah perilaku yang murni muncul dari benak pelanggan sehingga tidak bisa dipaksakan. 
Sebagaimana bagi umat Islam yang beriman, mereka mengakui akan hakikat iman dan hakikat agama tanpa ada dusta. Keimanan inilah yang dimaksu dengan loyalitas hamba kepada Tuhannya. Sebagaimana firman Allah Swt dalam QS. Al-Hujurat:15 yang artinya : sesungguhnya orangorang yang beriman itu hanyalah orang-orang yang percaya (beriman) kepada Allah dan Rasul-Nya, Kemudian mereka tidak ragu-ragu dan mereka berjuang (berjihad) dengan harta dan jiwa mereka pada jalan Allah. mereka Itulah orang-orang yang benar. Ayat tersebut dapat dikaitkan dengan loyalitas pelanggan, yang mana jika pelanggan sudah setia dan percaya pada suatu perusahaan atau merek maka ia akan menjadi loyal tak perduli dengan harga produk tersebut. Sebagaimana dikatakan oleh Barnes yang dikutip oleh Supranto dalam bukunya bahwa salah satu faktor yang berpotensi dalam menghasilkan keuntungan dari pelanggan yang bertahan lama (loyal) adalah mereka yang tidak begitu sensitif terhadap harga (Supranto 2001, 43). Hal tersebut dikarenakan, loyalitas adalah karakter psikologis yang terbentuk dari kepuasan pelanggan serta ikatan emosional yang terbentuk dari kualitas pelayanan, yang mengarah pada perasaan atau keadaan rela dan konsisten pada suatu pilihan, acuan dan kelebihan.

Untuk itu loyalitas nasabah sangat penting artinya bagi industri perbankan yang menjaga kelangsungan usahanya maupun kelangsungan kegiatan usahanya. Nasabah yang setia adalah mereka yang sangat puas dengan produk dan pelayanan tertentu, sehingga mempunyai antusiasme untuk memperkenalkannya kepada siapapun yang mereka kenal. Selanjutnya pada tahap berikutnya, nasabah yang sudah merasa puas dan loyal tersebut akan memperluas kesetiaan mereka pada produkproduk lain. Untuk mencapai nasabah yang loyal, Bank Syariah Mandiri harus terus melakukan inovasi terhadap setiap produk yang ditawarkan, agar nasabah tetap melakukan transaksi perbankan di Bank Syariah Mandiri KC Sangatta. Munculnya produk serupa yang ditawarkan oleh perusahaan perbankan lainnya membuat nasabah membandingkan produk dari Bank Syariah Mandiri dengan produk yang ditawarkan oleh perusahaan perbankan lainnya. Bagi bank menjadi sangat penting sekali untuk mengetahui bagaimana persepsi nasabah terhadap nisbah bagi 
hasil dan bonus yang diberikan oleh pihak Bank Syariah Mandiri KC Sangatta.

Berdasarkan uraian pada bagian pendahuluan maka rumusan masalahnya adalah: Apakah pendapatan bagi hasil berpengaruh terhadap loyalitas nasabah di Bank Syariah Mandiri KC Sangatta?; Apakah pemberian bonus berpengaruh terhadap loyalitas nasabah di Bank Syariah Mandiri KC Sangatta ?; Apakah secara simultan pendapatan bagi hasil dan pemberian bonus berpengaruh terhadap loyalitas nasabah di Bank Syariah Mandiri KC Sangatta?

\section{Kajian Pustaka}

\section{Nisbah Bagi Hasil}

Bagi hasil yaitu sistem yang meliputi tata cara pembagian hasil usaha antara penyedia dana dengan pengelola dana. Penentuan bagi hasil berdasarkan profit sharing maupun revenue sharing ditentukan dengan nisbah yang disepakati. Nisbah merupakan faktor penting dalam menentukan bagi hasil yang disepakati bersama antara kedua belah pihak yang melakukan transaksi pada bank syariah.

Adapun pengertian nisbah adalah besaran yang digunakan untuk pembagian keuntungan, mencerminkan imbalan yang berhak diterima oleh kedua pihak yang bermudharabah atas keuntungan yang diperoleh. Nisbah keuntungan harus diketahui dengan jelas oleh kedua pihak, inilah yang akan mencegah terjadinya perselisihan antara kedua belah pihak mengenai cara pembagian keuntungan. Jika terjadi perubahan nisbah harus berdasarkan kesepakatan kedua belah pihak. Pemilik dana tidak boleh meminta pembagian keuntungan dengan menyatakan nilai nominal tertentu karena dapat menimbulkan riba (Sri Nurhayati and Wasilah 2014, 133).

a. Faktor-faktor yang mempengaruhi bagi hasil : (Muh. Syafi'i Antonio, 2001: 139)

1. Faktor langsung

a) Investement rate

Merupakan persentase aktual dana yang diinvestasikan dari total dana. Jika bank menentukan investment 
rate sebesar $80 \%$, hal ini berarti $20 \%$ dari total dana di alokasikan untuk memenuhi likuiditas.

b) Jumlah dana yang tersedia untuk diinvestasikan merupakan jumlah dana dari berbagai sumber dana yang tersedia untuk di investasikan.

c) Nisbah (profit sharing ratio)

1) Salah satu ciri al-mudharabah adalah nisbah yang harus ditentukan dan disetujui pada awal perjanjian.

2) Nisbah antara satu bank dengan bank yang lainnya dapat berbeda.

3) Nisbah juga dapat berbeda dari waktu ke waktu dalam satu bank.

4) Nisbah juga dapat berbeda antara satu account dan account lainnya sesuai dengan besarnya dana dan jatuh temponya.

2. Faktor tidak langsung

3. Penentuan butir-butir pendapatan dan biaya mudharabah

a) Bank dan nasabah melakukan share dalam pendapatan dan biaya (profit and sharing). Pendapatan yang «dibagi hasilkan» merupakan pendapatan yang diterima dikurangi biaya-biaya.

b) Jika semua biaya ditanggung bank, hal ini disebut revenue sharing.

4. Kebijakan akunting (prinsip dan metode akunting) bagi hasil secara tidak langsung dipengaruhi oleh berjalannya aktivitas yang diterapkan, terutama sehubungan dengan pengakuan pendapatan dan biaya.

Dalam perbankan syariah, perangkat yang digunakan adalah sistem bagi hasil yang lebih mengutungkan kedua belah pihak. Bagi hasil dapat diartikan bahwa bank dan nasabah melakukan share atas keuntungan yang diperoleh. Prinsip bagi hasil (profit sharing) berdasarkan pada kaidah mudharabah. Dengan penabung, bank akan bertindak sebagai 
mudharib (pengelola dana) sementara penabung sebagai shahibul maal (penyandang dana). Di sisi lain, dengan peminjam dana, bank Islam akan bertindak sebagai shahibul maal sementara peminjam akan berfungsi sebagai mudharib.

Sistem bagi hasil merupakan sistem dimana dilakukannya perjanjian atau ikatan bersama di dalam melakukan kegiatan usaha. Di dalam usaha tersebut diperjanjikanya adanya pembagian hasil atas keuntungan yang akan didapat antara kedua pihak atau lebih. Bagi hasil dalam perbankan syariah merupakan ciri khusus yang ditawarkan kepada masyarakat, dan di dalam aturan syariah yang berkaitan dengan pembagian hasil usaha harus di tentukan terlebih dahulu pada awal terjadinya kontrak (akad). Besarnya penetuan porsi bagi hasil antara kedua belah pihak ditentukan sesuai kesepakatan bersama, dan harus terjadi dengan adanya kerelaan di masing-masing pihak tanpa adanya unsur paksaan.

\section{Bonus (prinsip wadi'ah)}

Bonus adalah kompensasi tambahan yang diberikan kepada seorang karyawan yang nilainya di atas gaji normalnya. Bonus bisa digunakan sebagai penghargaan terhadap pencapaian tujuan-tujuan spesifik yang ditetapkan oleh perusahaan, atau untuk dedikasinya kepada perusahaan. Tabungan wadi'ah merupakan tabungan yang dijalankan berdasarkan akad wadi'ah, yakni titipan murni yang harus dijaga dan dikembalikan setiap saat sesuai dengan kehendak pemiliknya. Berkaitan dengan produk tabungan wadiah, bank syariah menggunakan akad wadiah yad adhdhamanah (Karim 2011, 345). Tabungan wadiah dengan akad wadi'ah yad adh-dhamanah adalah jasa penitipan dana dalam hal ini penitip atau nasabah dapat mengambil dana tersebut sewaktu-waktu. Dengan sistem wadiah bank dibolehkan memberikan bonus kepada nasabah sebagai bentuk kompensasi kepada nasabah atas kepercayaan nasabah menabung di bank tersebut.

Saat ini produk tabungan wadiah mulai mendapat perhatian dari masyarakat. Tabungan wadi'ah ini menarik karena merupakan salah satu bentuk produk tabungan perbankan syariah yang memberikan rasa aman. Dalam hal ini dana simpanan nasabah tidak mungkin berkurang, bahkan bisa bertambah dari saldo awal pada jangka waktu tertentu. Penambahan 
saldo tersebut berasal dari bonus yang diberikan oleh pihak bank. Bonus yang diberikan tersebut tidak boleh diperjanjikan di awal, dan murni kebijakan bank semata yang bersifat sukarela (Karim 2011, 346).

Dengan adanya bonus yang diberikan maka diharapkan masyarakat tertarik untuk menyimpan dananya di Bank Syariah. Asumsinya dengan tinggi rendahnya bonus dapat menggambarkan kinerja keuangan di perbankan. Semakin tinggi nilai bonus yang diberikan berarti kinerja perbankan semakin baik. Semakin tinggi tingkat pendapatan bank maka akan berpengaruh pada porsi bonus tabungan wadiah.

\section{Loyalitas Pelanggan atau Nasabah}

a. Pengertian Loyalitas Pelanggan

Kesetiaan (Loyalitas) adalah sebuah kata bergaya kuno yang mendiskripsikan keadaan dimana seseorang menyerahkan seluruh jiwa dan raganya pada satu Negara, keluarga dan teman-temannya.

Loyalitas adalah komitmen pelanggan bertahan secara mendalam untuk berlangganan kembali atau melakukan pembelian ulang produk/jasa terpilih secara konsisten di masa yang akan datang, meskipun pengaruh situasi dan usaha pemasaran mempunyai potensi untuk melakukan perubahan situasi.

Pemahaman loyalitas pelanggan sebenarnya tidak hanya dilihat dari transaksinya saja atau pembelian berulang (repeat customer). Ada beberapa ciri sebuah pelanggan bisa dianggap loyal. Antara lain: (Philip Kotler, 2003: 111-112)
A. Pelanggan yang melakukan pembelian ulang secara teratur
B. Pelanggan yang membeli untuk produk yang lain di tempat yang sama
C. Pelanggan yang mereferensikan kepada orang lain
D. Pelanggan yang tidak dapat dipengaruhi oleh pesaing untuk pindah

b. Perspektif Loyalitas Pelanggan

Saat ini tugas dan kewajiban perusahaan tidaklah ringan. Mereka dihadapkan pada tuntutan tidak hanya membuat para 
konsumen tertarik, namun juga membuat konsumen tersebut menjadi sumber laba bagi perusahaan tetapi juga menbuat pelanggannya setia. Loyalitas adalah sikap dari nasabah dalam menentukan pilihannya untuk tetap menggunakan produk atau jasa dari suatu perusahaan. Sikap menentukan pilihan tersebut juga untuk membuat komitmen dan melakukan pembelian ulang pada perusahaan tersebut.

Loyalitas nasabah akan melahirkan perilaku dan tindakan nasabah seperti:

1) Perilaku nasabah yang bersifat memberikan rekomendasi untuk mengajak orang lain melakukan pembelian atau menggunakan produk tersebut.

2) Nasabah akan melakukan aktifitas transaksi atau mempergunakan segala bentuk layanan yang ditawarkan oleh pihak perbankan.

3) Nasabah akan menjadikan perbankan tersebut sebagai pilihan pertama dalam mempergunakan jasa keuangan.

4) Word of mouth yaitu perilaku nasabah untuk membicarakan hal-hal yang bagus terhadap produk dari bank tersebut ke orang lain.

Membangun loyalitas pelanggan merupakan kebijakan strategis bagi perusahaan. Karena perusahaan memandang loyalitas pelanggan merupakan bagian dari strategi perusahaan dalam menghadapi pesaing dan menghubungkan perusahaan dengan pasar (konsumen). Loyalitas pelanggan sangat dibutuhkan sebagai elemen dalam strategi pemasaran yang kompetitif. Secara khusus dalam menghadapi kondisi pasar yang semakin kompetitif, perusahaan seringkali menyadarkan masa depan mereka pada loyalitas pelanggan.

\section{Metode Penelitian}

Jenis dari penelitian ini adalah deskriptif kuantitatif. Metode penelitian kuantitatif adalah suatu metode penelitian yang berlandaskan pada filsafat positivisme, digunakan untuk meneliti pada populasi atau 
sampel tertentu, teknik pengambilan sampel pada umumnya dilakukan secara random, pengumpulan data menggunakan instrumen penelitian, analisis data bersifat kuantitatif dengan tujuan menguji hipotesis yang telah ditetapkan. (Sugiyono, 2010: 14). Obyek penelitian ini adalah nasabah Bank Syariah Mandiri KC. Sangatta tahun 2017. Teknik sampling dalam penelitian ini menggunakan simple random sampling dan teknik analisis menggunakan analisis jalur (path analysis).

\section{Pembahasan}

\section{a. Analisa Analisis Jalur}

Teknik pengolahan data selanjutnya dalam menyelesaikan penelitian ini adalah dengan menggunakan analisis jalur (path analysis).

\section{Pengujian Hubungan Antar Sub Variabel}

Dalam metode analisis jalur, untuk mencari hubungan kausal atau pengaruh variabel-variabel penelitian, terlebih dahulu dihitung matriks korelasi dari variabel-variabel penelitian.

Tabel 1

\section{Korelasi antar sub Variabel}

Correlations

\begin{tabular}{|ll|r|r|r|}
\hline & & \multicolumn{1}{c|}{$\begin{array}{c}\text { Pendapatan } \\
\text { Bagi Hasil }\end{array}$} & $\begin{array}{l}\text { Pemberian } \\
\text { Bonus }\end{array}$ & \multicolumn{1}{c|}{$\begin{array}{c}\text { Loyalitas } \\
\text { Nasabah }\end{array}$} \\
\hline $\begin{array}{l}\text { Pendapatan } \\
\text { Bagi Hasil }\end{array}$ & $\begin{array}{l}\text { Pearson } \\
\text { Correlation }\end{array}$ & 1 & $.326^{* *}$ & $.463^{* *}$ \\
\cline { 2 - 5 } & Sig. (2-tailed) & & .001 & .000 \\
\hline $\begin{array}{l}\text { Pemberian } \\
\text { Bonus }\end{array}$ & $\begin{array}{l}\text { Pearson } \\
\text { Correlation }\end{array}$ & 98 & 98 & 98 \\
\cline { 2 - 5 } & Sig. (2-tailed) & $.326^{* *}$ & 1 & $.417^{* *}$ \\
\cline { 2 - 5 } $\begin{array}{l}\text { Loyalitas } \\
\text { Nasabah }\end{array}$ & Pearson & .001 & & .000 \\
& Correlation & $.463^{* *}$ & $.417^{* *}$ & 1 \\
& Sig. (2-tailed) & .000 & .000 & \\
\cline { 2 - 6 } & $\mathrm{N}$ & 98 & 98 & 98 \\
\hline
\end{tabular}

**. Correlation is significant at the 0.01 level (2-tailed).

Sumber : Data Primer yang diolah, 2017. 
Dari tabel 1 di atas dapat diketahui nilai korelasi antar variabel. Angka koefisien korelasi bertanda positif menunjukkan bahwa hubungan antara kedua variabel tersebut bersifat berbanding lurus, artinya peningkatan satu variabel akan diikuti oleh peningkatan variabel lain. Untuk penentuan keeratan hubungan digunakan kriteria sebagai berikut:

$\begin{array}{ll}0,81-1,000 & =\text { Hubungan yang sangat kuat } \\ 0,60-0,799 & =\text { Hubugan yang kuat } \\ 0,40-0,599 & =\text { Hubungan yang cukup kuat } \\ 0,20-0,399 & =\text { Hubungan yang rendah } \\ 0,00-0,199 & =\text { Hubungan yang sangat rendah }\end{array}$

Tabel 2

Pengujian Hubungan antar sub Variabel

\begin{tabular}{|c|c|c|c|c|}
\hline Hubungan & $\begin{array}{c}\text { Koefisien } \\
\text { Korelasi }\end{array}$ & Kategori & Probabilitas & Keterangan \\
\hline $\begin{array}{l}\text { Loyalitas } \\
\text { Nasabah } \\
(\mathrm{Y}) \text { dengan } \\
\text { Pendapatan } \\
\text { Bagi Hasil } \\
(\mathrm{X} 1)\left(\mathrm{rYX}_{1}\right)\end{array}$ & 0,463 & Cukup Kuat & 0,000 & Signifikan \\
\hline $\begin{array}{l}\text { Loyalitas } \\
\text { Nasabah } \\
(\mathrm{Y}) \text { dengan } \\
\text { Pemberian } \\
\text { Bonus (X2) } \\
\left(\mathrm{rYX}_{2}\right) \\
\end{array}$ & 0,417 & Cukup Kuat & 0,000 & Signifikan \\
\hline $\begin{array}{l}\text { Pendapatan } \\
\text { Bagi Hasil } \\
\text { (X1) } \\
\text { dengan } \\
\text { Pemberian } \\
\text { Bonus (X2) } \\
\left.\text { (rX, } X_{2}\right)\end{array}$ & 0,326 & Rendah & 0,001 & Signifikan \\
\hline
\end{tabular}

Sumber : Data Primer yang diolah, 2017.

Berdasarkan hasil pengujian tabel 2 di atas, diketahui bahwa ketiga hubungan yang memiliki hubungan yang signifikan yaitu antara Loyalitas Nasabah (Y) dengan Pendapatan Bagi Hasil (X1), Loyalitas Nasabah 
(Y) dengan Pemberian Bonus (X2), dan Pendapatan Bagi Hasil (X1) dengan Pemberian Bonus (X2).

\section{Pengujian secara simultan/bersama-sama (Uji F)}

Tabel 3

\section{Pengujian Analisis Varians}

\begin{tabular}{|c|c|c|c|c|c|c|}
\hline \multicolumn{7}{|c|}{ ANOVA $^{b}$} \\
\hline \multicolumn{2}{|c|}{ Model } & $\begin{array}{c}\text { Sum of } \\
\text { Squares }\end{array}$ & Df & Mean Square & $\mathrm{F}$ & Sig. \\
\hline 1 & Regression & 144.610 & 2 & 72.305 & 19.745 & $.000^{\mathrm{a}}$ \\
\hline & Residual & 347.890 & 95 & 3.662 & & \\
\hline & Total & 492.500 & 97 & & & \\
\hline
\end{tabular}

a. Predictors: (Constant), Pemberian Bonus, Pendapatan Bagi Hasil

b. Dependent Variable: Loyalitas Nasabah

Sumber : Data Primer yang diolah, 2017.

Pada tabel 3 analisis varians (Anova) ditampilkan hasil uji F yang dapat dipergunakan untuk menguji model apakah variabel pendapatan bagi hasil dan pemberian bonus secara simultan berpengaruh signifikan terhadap loyalitas nasabah.

Pengujian dilakukan dengan uji F, dan hipotesis yang diajukan adalah :

$\mathrm{H}_{0}: \mathrm{PYX}_{1}=\mathrm{PYX}_{2}=0$

$\mathrm{H}_{\mathrm{a}}: \mathrm{PYX}_{1}=\mathrm{PYX}_{2} \neq 0$

Kriteria pengujian berdasarkan perbandingan nilai $\mathrm{F}_{\text {hitung }}$ dengan $\mathrm{F}_{\text {tabel }}$ :

Jika $\mathrm{F}_{\text {hitung }}>\mathrm{F}_{\text {tabel }}$ maka $\mathrm{H}_{0}$ ditolak

Jika $\mathrm{F}_{\text {hitung }}<\mathrm{F}_{\text {tabel }}$ maka $\mathrm{H}_{0}$ diterima

Dari perhitungan didapat nilai $\mathrm{F}_{\text {hitung }}$ sebesar 19.745, dengan tingkat signifikansi sebesar 5\% dan $\mathrm{df}_{1}=2, \mathrm{df}_{2}=95$, diketahui nilai $\mathrm{F}_{\text {tabel }}=3,09$. Karena nilai $\mathrm{F}_{\text {hitung }}(19.745)>\mathrm{F}_{\text {tabel }}(3,09)$ maka $_{0}$ ditolak atau terdapat kecocokan antara model dengan data. Sehingga dapat disimpulkan bahwa aspek variabel pendapatan bagi hasil dan pemberian bonus secara simultan berpengaruh signifikan terhadap loyalitas nasabah. Dan jika dilihat menggunakan nilai signifikansi, diketahui bahwa nilai sig. (0,000 $<0,05$ ) sehingga memiliki kesimpulan yang sama dengan uji $\mathrm{F}$ yaitu 
terdapat kecocokan antara model dengan data. Sehingga model analisis jalur yang didapat layak untuk digunakan.

\section{Pengujian secara individu/parsial (Uji t)}

\section{Tabel 4}

\section{Pengujian secara Parsial}

\section{Coefficients $^{a}$}

\begin{tabular}{|c|c|c|c|c|}
\hline \multirow{2}{*}{\multicolumn{2}{|c|}{ Model }} & $\begin{array}{l}\text { Standardized } \\
\text { Coefficients }\end{array}$ & \multirow[t]{2}{*}{$\mathrm{t}$} & \multirow[t]{2}{*}{ Sig. } \\
\hline & & Beta & & \\
\hline \multirow{3}{*}{1} & (Constant) & & 4.408 & .000 \\
\hline & Pendapatan Bagi Hasil & .366 & 4.018 & .000 \\
\hline & Pemberian Bonus & .297 & 3.260 & .002 \\
\hline
\end{tabular}

a. Dependent Variable: Loyalitas Nasabah

Sumber : Data Primer yang diolah, 2017.

Diketahui : $\mathrm{Y}=\mathrm{PYX}_{\mathrm{i}} \mathrm{X}_{1}+\mathrm{PYX}_{\mathrm{i}} \mathrm{X}_{2}+\mathrm{e}$

Pengambilan keputusan didasarkan atas dua metode, yaitu :

1) Berdasarkan perbandingan nilai $t_{\text {hitung }}$ dengan $t_{\text {tabel }}$

Jika $t_{\text {hitung }}>\mathrm{t}_{\text {tabel }}$ maka $\mathrm{H}_{0}$ ditolak

Jika $t_{\text {hitung }}<\mathrm{t}_{\text {tabel }}$ maka $\mathrm{H}_{0}$ diterima

2) Berdasarkan nilai probabilitas dengan $a=0,05$ :

Jika probabilitas $>0,05$, maka $\mathrm{H}_{0}$ diterima

Jika probabilitas $<0,05$, maka $\mathrm{H}_{0}$ ditolak

Berikut adalah kriteria pengujiannya :

1) Menguji signifikansi koefisien pendapatan bagi hasil pada model analisis jalur :

Berikut adalah hipotesis yang diajukan :

$\mathrm{H}_{0}: \mathrm{PYX}_{\mathrm{i}} \mathrm{X}_{1}=0$ artinya koefisien $\mathrm{X}_{1}$ tidak signifikan

$\mathrm{H}_{\mathrm{a}}: \mathrm{PYX}_{\mathrm{i}} \mathrm{X}_{1} \neq 0$ artinya koefisien $\mathrm{X}_{1}$ signifikan

Dari hasil pengolahan data diketahui bahwa nilai $t_{\text {hitung }}$ untuk koefisien pendapatan bagi hasil adalah 4.018 dan nilai $t_{\text {tabel }}$ sebesar 1,660. Karena $t_{\text {hitung }}>t_{\text {tabel }}(4.018>1,660)$, maka $H_{0}$ ditolak, sehingga 
dapat disimpulkan bahwa pendapatan bagi hasil berpengaruh signifikan terhadap loyalitas nasabah.

Untuk nilai probabilitas pada kolom sig. adalah 0,000 atau probabilitas lebih kecil dari 0,05 $(0,000<0,05)$. Dengan demikian $\mathrm{H}_{0}$ ditolak, sehinggan kesimpulannya sama dengan uji t yaitu pendapatan bagi hasil berpengaruh signifikan terhadap loyalitas nasabah.

2) Menguji signifikansi koefisien pemberian bonus pada model analisis jalur :

Berikut adalah hipotesis yang diajukan :

$\mathrm{H}_{0}: \mathrm{PYX}_{\mathrm{i}} \mathrm{X}_{2}=0$ artinya koefisien $\mathrm{X}_{2}$ tidak signifikan

$\mathrm{H}_{\mathrm{a}}: \mathrm{PYX}_{\mathrm{i}} \mathrm{X}_{2} \neq 0$ artinya koefisien $\mathrm{X}_{2}$ signifikan

Dari hasil pengolahan data diketahui bahwa nilai $\mathrm{t}_{\text {hitung }}$ untuk koefisien pemberian bonus adalah 3.260 dan nilai $t_{\text {tabel }}$ sebesar 1,660. Karena $t_{\text {hitung }}>t_{\text {tabel }}(3.260>1,660)$, maka $H_{0}$ ditolak, sehingga dapat disimpulkan bahwa pemberian bonus berpengaruh signifikan terhadap loyalitas nasabah.

Untuk nilai probabilitas pada kolom sig. adalah 0,002 atau probabilitas lebih kecil dari 0,05 $(0,000<0,05)$. Dengan demikian $\mathrm{H}_{0}$ ditolak, sehinggan kesimpulannya sama dengan uji t yaitu pemberian bonus berpengaruh signifikan terhadap loyalitas nasabah.

Untuk lebih jelasnya dapat dilihat pada tabel 5 pengujian individual berikut ini :

Tabel 5

Pengujian Individual

\begin{tabular}{|c|c|c|c|c|l|}
\hline No & Hipotesis & $\begin{array}{c}\text { Koefisien } \\
\text { Jalur }\end{array}$ & $\mathbf{t}_{\text {hitung }}$ & \multicolumn{1}{|c|}{$\mathbf{t}_{\text {tabel }}$} & \multicolumn{1}{|c|}{ Keterangan } \\
\hline 1 & $\mathrm{PYX}_{\mathrm{i} \mathrm{X}_{1} \neq 0}$ & $\mathrm{PYX}_{\mathrm{i}}=0,366$ & 4.018 & 1,660 & $\mathrm{H}_{0}$ ditolak \\
\hline 2 & $\mathrm{PYX}_{\mathrm{i} \mathrm{X}_{2} \neq 0}$ & $\mathrm{PYX}_{\mathrm{i}}=0,297$ & 3.260 & 1,660 & $\mathrm{H}_{0}$ ditolak \\
\hline
\end{tabular}

Sumber : Data Primer yang diolah, 2017. 


\section{Pembahasan Hasil Penelitian}

Dalam penentuan variabel penelitian secara keseluruhan diperoleh nilai koefisien jalur dari penjumlahan seluruh variabel penyebab terhadap variabel akibat. Nilai koefisien jalur variabel pendapatan bagi hasil dan pemberian bonus terhadap loyalitas nasabah diolah dengan menggunakan bantuan software SPSS. Berikut adalah tabel 6 yang menunjukkan pengujian individu :

\section{Tabel 6}

\section{Pengujian Individual}

Coefficients $^{\mathrm{a}}$

\begin{tabular}{|ll|r|}
\hline \multirow{2}{*}{ Model } & \multicolumn{2}{|c|}{ Standardized Coefficients } \\
\cline { 3 - 3 } & & \multicolumn{1}{|c|}{ Beta } \\
\hline & (Constant) & .366 \\
\cline { 2 - 3 } & Pendapatan Bagi Hasil & .297 \\
\cline { 2 - 3 } & Pemberian Bonus & \\
\hline
\end{tabular}

a. Dependent Variable: Loyalitas Nasabah

Sumber : Data Primer yang diolah, 2017.

Berdasarkan hasil pengolahan data pada tabel 6 di atas, maka diperoleh koefisien-koefisien jalur sebagai berikut :

\begin{tabular}{|c|}
\hline PYX $_{\mathrm{i}} \mathrm{X}_{1}=0,366$ \\
\hline $\mathrm{PYX}_{\mathrm{i}} \mathrm{X}_{2}=0,297$ \\
\hline
\end{tabular}

Jadi, persamaan analisis jalur yang terbentuk adalah sebagai berikut :

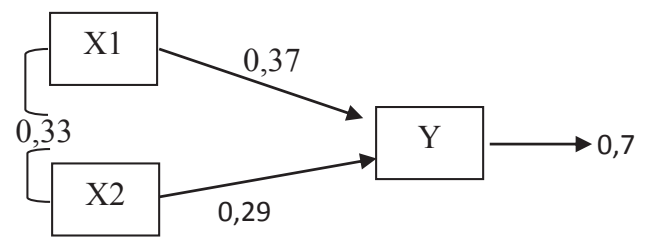

$$
\begin{aligned}
& Y=P Y X_{i} X_{1}+P Y X_{i} X_{2}+e \\
& Y=0,366 X_{1}+0,297 X_{2}
\end{aligned}
$$


Besarnya koefisien jalur keseluruhan variabel dapat dilihat pada diagram jalur sebagai berikut :

Berdasarkan diagram di atas, dapat diketahui bahwa pendapatan bagi hasil (X1) dan pemberian bonus (X2) merupakan dua variabel penyebab yang satu dengan yang lainnya mempunyai kaitan korelatif. Selain itu, variabel tersebut secara bersama-sama (X1 dan X2) mempengaruhi variabel loyalitas nasabah (Y).

Berikut adalah tabel 7 tentang perhitungan pengaruh langsung dan tidak langsung dari setiap variabel.

Tabel 7

Pengaruh Langsung dan Tidak Langsung $X_{1}$ terhadap $Y$

\begin{tabular}{|c|l|l|c|}
\hline \multicolumn{2}{|c|}{ Pengaruh Langsung dan Tidak Langsung } & $\begin{array}{c}\text { Besar } \\
\text { Kontribusi }\end{array}$ \\
\hline X1 langsung & $\mathrm{PYX}_{1} \times \mathrm{PYX}_{1}$ & $0,366 \times 0,366$ & 0,133956 \\
\hline $\mathrm{X} 1$ melalui X2 & $\mathrm{PYX}_{1} \times \mathrm{rx}_{1} \mathrm{x}_{2} \times \mathrm{PYX}_{2}$ & $0,366 \times 0,326 \times 0,297$ & 0,035437 \\
\hline \multicolumn{2}{|c|}{ Total pengaruh X1 terhadap Y } & 0,169393 \\
\hline
\end{tabular}

Sumber : Data Primer yang diolah, 2017.

Dari tabel 7 di atas dapat diketahui bahwa pengaruh langsung variabel pendapatan bagi hasil $\left(\mathrm{X}_{1}\right)$ terhadap loyalitas nasabah $(\mathrm{Y})$ adalah sebesar 0,133956 atau 13,3956\% dan pengaruh tidak langsung melalui pemberian bonus $\left(\mathrm{X}_{2}\right)$ adalah 0,035437 atau $3,5437 \%$, sehingga total pengaruh yang diberikan variabel pendapatan bagi hasil $\left(\mathrm{X}_{1}\right)$ adalah 0,169393 atau sebesar $16,9393 \%$ terhadap loyalitas nasabah (Y). Hal ini berarti menunjukkan bahwa pendapatan bagi hasil memiliki pengaruh yang cukup terhadap loyalitas nasabah.

Tabel 8

Pengaruh Langsung dan Tidak Langsung $\mathrm{X}_{2}$ terhadap $\mathrm{Y}$

\begin{tabular}{|c|l|l|c|}
\hline \multicolumn{2}{|c|}{ Pengaruh Langsung dan Tidak Langsung } & $\begin{array}{c}\text { Besar } \\
\text { Kontribusi }\end{array}$ \\
\hline X2 langsung & $\mathrm{PYX}_{2} \times \mathrm{PYX}_{2}$ & $0,297 \times 0,297$ & 0,088209 \\
\hline
\end{tabular}




\begin{tabular}{|l|l|l|l|}
\hline $\mathrm{X} 2$ melalui X1 & $\mathrm{PYX}_{2} \times \mathrm{rx}_{1} \mathrm{x}_{2} \times \mathrm{PYX}_{1}$ & $0,297 \times 0,326 \times 0,366$ & 0,035437 \\
\hline Total pengaruh X1 terhadap Y & 0,123646 \\
\hline
\end{tabular}

Sumber : Data Primer yang diolah, 2017.

Dari tabel 8 di atas dapat diketahui bahwa pengaruh langsung variabel pemberian bonus $\left(\mathrm{X}_{2}\right)$ terhadap loyalitas nasabah $(\mathrm{Y})$ adalah sebesar 0,088209 atau 8,8209\% dan pengaruh tidak langsung melalui pendapatan bagi hasil $\left(\mathrm{X}_{1}\right)$ adalah 0,035437 atau 3,5437\%, sehingga total pengaruh yang diberikan variabel pemberian bonus $\left(\mathrm{X}_{2}\right)$ adalah 0,123646 atau sebesar $12,3646 \%$ terhadap loyalitas nasabah (Y). Hal ini berarti menunjukkan bahwa pemberian bonus memiliki pengaruh yang cukup terhadap loyalitas nasabah.

Berikut adalah pengaruh total kedua variabel terhadap loyalitas nasabah.

$$
\begin{aligned}
& =\text { Pengaruh Total X1 + Pengaruh Total X2 } \\
& =16,9393 \%+12,3646 \% \\
& =29,3039 \%
\end{aligned}
$$

Jadi, pengaruh secara keseluruhan terhadap variabel $\mathrm{Y}$ sebesar 29,3039\%.

Hal tersebut sebagaimana dijelaskan pada tabel 9 sebagai berikut :

Tabel 9

Model Summary

\begin{tabular}{|c|c|c|c|c|}
\hline Model & $\mathrm{R}$ & R Square & $\begin{array}{c}\text { Adjusted R } \\
\text { Square }\end{array}$ & $\begin{array}{c}\text { Std. Error of the } \\
\text { Estimate }\end{array}$ \\
\hline 1 & $.542^{\mathrm{a}}$ & .294 & .279 & 1.914 \\
\hline
\end{tabular}

a. Predictors: (Constant), Pemberian Bonus, Pendapatan Bagi Hasil

Sumber : Data Primer yang diolah, 2017.

Pada tabel 9 di atas diketahui model analisis jalur dengan nilai koefisien korelasi parsial (R) sebesar 0,542, nilai koefisien determinasi (R Square) sebesar 0,294 (29,4\%). Hal ini menunjukkan bahwa dengan menggunakan model analisis jalur yang didapatkan dimana variabel penyebab yaitu pendapatan bagi hasil $\left(\mathrm{X}_{1}\right)$ dan pemberian bonus $\left(\mathrm{X}_{2}\right)$ 
memiliki pengaruh terhadap variabel loyalitas nasabah (Y) sebesar 29,4\%. Sedangkan sisanya yaitu 70,6\% kemungkinan terdapat pada aspek-aspek lainnya yang memiliki pengaruh pada variabel loyalitas nasabah (Y) dan tidak diteliti dalam penelitian ini. Hal ini sesuai dengan nilai erorr yang muncul pada path di atas yaitu sebesar 0,706 atau 70,6\%.

Dari uraian di atas dapat diketahui dan disimpulkan bahwa setiap variabel masing-masing item pertanyaan dijawab dengan mayoritas jawaban menyatakan setuju dan netral. Oleh karena itu, hal ini sejalan dengan pengujian hipotesa alternatif ( $\mathrm{Ha}$ ) yang menyatakan bahwa terdapat pengaruh yang signifikan antara variabel pendapatan bagi hasil dan pemberian bonus terhadap loyalitas nasabah baik secara parsial (individu) maupun secara simultan (bersama-sama) dengan ditunjukkan p value 0,000 yang lebih kecil dari taraf signifikansi 0,05 . Untuk itu hal ini menunjukkan bahwa pendapatan bagi hasil dan pemberian bonus berpengaruh terhadap loyalitas nasabah di Bank Syariah Mandiri KC Sangatta. Dan hal tersebut sudah sesuai dengan salah satu teori tentang loyalitas pelanggan yang dikemukakan oleh Philip Kotler dimana loyalitas adalah komitmen pelanggan bertahan secara mendalam untuk berlangganan kembali atau melakukan pembelian ulang produk/jasa terpilih secara konsisten di masa yang akan datang, karena menurut Kotler Kualitas pelayanan atau suatu produk adalah salah satu faktor utama dalam menciptakan loyalitas pada nasabah. Nasabah akan loyal apabila suatu lembaga keuangan khususnya BSM dapat memberikan pelayanan maupun memberikan produk yang terbaik untuk nasabahnya.

\section{Kesimpulan}

Berdasarkan hasil penelitian yang telah dibahas mengenai pendapatan bagi hasil dan pemberian bonus terhadap loyalitas nasabah di Bank Syariah Mandiri KC Sangatta dapat diambil kesimpulan bahwa:

Pertama, variabel pendapatan bagi hasil $\left(\mathrm{X}_{1}\right)$ memiliki hubungan dan berpengaruh secara signifikan terhadap loyalitas nasabah $(\mathrm{Y})$. Hal tersebut ditunjukkan dari hasil olah data (pengujian secara individu/ parsial) dengan nilai $t_{\text {hitung }}$ yang diperoleh sebesar 4.018 dan nilai $t_{\text {tabel }}$ sebesar 1,660 dengan nilai probabilitas pada kolom sig. adalah 0,000 atau probabilitas lebih kecil dari 0,05 $(0,000<0,05)$. Karena $t_{\text {hitung }}>t_{\text {tabel }}$ 
$(4.018>1,660)$ dan nilai probabilitas $0,000<0,05$, maka $\mathrm{H}_{0}$ ditolak, sehingga dapat disimpulkan bahwa pendapatan bagi hasil berpengaruh signifikan terhadap loyalitas nasabah. Besarnya pengaruh langsung dari variabel pendapatan bagi hasil terhadap loyalitas nasabah adalah sebesar 0,133956 atau 13,3956\% dan pengaruh tidak langsung melalui pemberian bonus adalah 0,035437 atau 3,5437\%, sehingga total pengaruh yang diberikan variabel pendapatan bagi hasil $\left(\mathrm{X}_{1}\right)$ adalah 0,169393 atau sebesar $16,9393 \%$.

Kedua, sama halnya pada variabel pemberian bonus $\left(\mathrm{X}_{2}\right)$ terhadap loyalitas nasabah, dimana nilai $t_{\text {hitung }}$ yang diperoleh sebesar 3.260 dan nilai $t_{\text {tabel }}$ sebesar 1,660 dengan nilai probabilitas pada kolom sig. adalah 0,002 atau probabilitas lebih kecil dari $0,05(0,000<0,05)$. Karena $\mathrm{t}_{\text {hitung }}>\mathrm{t}_{\text {tabel }}(3.260>1,660)$ dan nilai probabilitas $0,002<0,05$, maka $\mathrm{H}_{0}$ ditolak, sehingga dapat disimpulkan bahwa pemberian bonus juga berpengaruh signifikan terhadap loyalitas nasabah. Besarnya pengaruh langsung pemberian bonus terhadap loyalitas nasabah adalah sebesar 0,088209 atau 8,8209\% dan pengaruh tidak langsung melalui pendapatan bagi hasil adalah 0,035437 atau 3,5437\%, sehingga total pengaruh yang diberikan variabel pemberian bonus $\left(\mathrm{X}_{2}\right)$ adalah 0,123646 atau sebesar $12,3646 \%$.

Ketiga, pengujian secara simultan/bersama-sama juga dilakukan guna untuk mengetahui seberapa besar pengaruh pendapatan bagi hasil dan pemberian bonus terehadap loyalitas nasabah secara bersama-sama. Dan berdasarkan hasil olah data diperoleh nilai $F_{\text {hitung }}$ sebesar 19.745 dan nilai $\mathrm{F}_{\text {tabel }}$ sebesar 3,09. Karena nilai $\mathrm{F}_{\text {hitung }}(19.745)>\mathrm{F}_{\text {tabel }}(3,09)$ maka $\mathrm{H}_{0}$ ditolak atau terdapat kecocokan antara model dengan data. Sehingga dapat disimpulkan bahwa aspek variabel pendapatan bagi hasil dan pemberian bonus secara simultan berpengaruh signifikan terhadap loyalitas nasabah. Dan jika dilihat menggunakan nilai signifikansi, diketahui bahwa nilai sig. $(0,000<0,05)$ sehingga memiliki kesimpulan yang sama dengan uji $\mathrm{F}$ yaitu terdapat kecocokan antara model dengan data. Sehingga model analisis jalur yang didapat layak untuk digunakan.

Berdasarkan uraian di atas dapat diketahui dan disimpulkan bahwa hasil penelitian sejalan dengan pengajuan hipotesa alternatif $(\mathrm{Ha})$ yang menyatakan bahwa terdapat pengaruh yang signifikan antara variabel 
pendapatan bagi hasil dan pemberian bonus terhadap loyalitas nasabah baik secara parsial (individu) maupun secara simultan (bersamasama). Untuk itu hal ini menunjukkan bahwa pendapatan bagi hasil dan pemberian bonus berpengaruh terhadap loyalitas nasabah di Bank Syariah Mandiri KC Sangatta, dengan nilai yang diperoleh dari variabel penyebab yaitu pendapatan bagi hasil $\left(\mathrm{X}_{1}\right)$ dan pemberian bonus $\left(\mathrm{X}_{2}\right)$ terhadap variabel loyalitas nasabah $(\mathrm{Y})$ dengan total pengaruh sebesar $29,4 \%$. Sedangkan sisanya yaitu $70,6 \%$ kemungkinan terdapat pada aspek-aspek lainnya yang memiliki pengaruh pada variabel loyalitas nasabah (Y) dan tidak diteliti dalam penelitian ini. 


\section{DAFTAR PUSTAKA}

Alma, Buchari dan Donni Juni Priansa, Manajemen Bisnis Syariah, Bandung: Alfabeta, 2009.

Al Arif, M. Nur Rianto dan Ika Nurhikmah, "Determinan Pembiayaan Bagi Hasil Perbankan Syariah Di Indonesia: Model Regresi Panel” Al Falah: Journal of Islamic Economics, Vol. 2, No. 1, 2017.

Antonio, Muhammad Syafi'i, Bank Syariah Suatu Pengenalan Umum, Jakarta: Tazkia Institute dan BI, 1999, Cet. 1.

Muhammad Syafi'i Antonio , Bank Syariah Dari Teori ke Praktik, Jakarta: Gema Insani Press, 2001.

Bungin, Burhan, Metode Penelitian Kuantitatif, Jakarta: Kencana, 2011, Cet. 6.

Djumhana, Muh., Hukum Perbankan di Indonesia, Bandung: PT. Citra Aditya Bhakti, 2006.

Falah, Syamsul, "Pola Bagi Hasil Pada Perbankan Syariah”, Makalah disampaikan pada Seminar Ekonomi Islam, Jakarta, 29 April 2003.

Hasil wawancara dengan Nanin (Marketing Bank Syariah Mandiri), tanggal 06 April 2017.

Karim, Adiwarman, Bank Islam : Analisis Fiqih dan Keuangan, Jakarta: PT. Raja Grafindo Persada, 2011, Cet. 8.

Kotler, Philip, Dasar-dasar Manajemen Pemasaran, Jakarta: PT. Indeks, 2003.

Lubis, Indra Jaya, “Tinjauan Mengenai Konsepsi Akuntansi Bank Syari’ah”, Disampaikan pada pelatihan Praktek Akuntansi Bank Syariah BEMJEkonomi Islam, UIN Syarif Hidayatullah, Jakarta, 2001.

Muhammad, Manajemen Bank Syari'ah, Yogyakarta: UPP AMP YKPN, 2002.

Mujibatun, Siti, “Prospek Ekonomi Syariah Melalui Produk Mudarabah dalam Memperkuat Rektor Riil", dalam Jurnal Economica Volume IV/Edisi 1/Mei 2013.

Nurhayati, Sri dan Wasilah, Akuntansi Syariah Di Indonesia, Jakarta: Salemba Empat, 2014. 
Ridwan, "Konstruksi Akad-Akad Ekonomi Syariah” Dalam Ijtihad, Jurnal Wacana Hukum Islam Dan Kemanusiaan Vol. 15, No. 2, 2015.

Riduwan, Metode dan Teknik Menyusun Proposal Penelitian, Bandung: Alfabeta, 2010, Cet. 3.

, Skala Pengukuran Variabel-Variabel Penelitian, Bandung: Alfabeta, 2011.

Saeed, Abdullah, Bank Islam dan Bunga:Studi Kritis dan Interpretasi Kontemporer tentang Riba dan Bunga, Yogyakarta: Pustaka Pelajar, 2003, Cet. 1.

Siregar, Syofian, Metode Penelitian Kuantitatif : Dilengkapi Perbandingan Manual \& SPSS, Jakarta: Prenadamedia Group, 2013, Cet. 1.

Somad, Rismi dan Donni Juni Priansa, Manajemen Komunikasi: Mengembangkan Bisnis Berorientasi Pelanggan, Bandung: Alfabeta, 2014.

Subagyo, dkk., Bank dan Lembaga Keuangan Lainnya, Yogyakarta: STIE YKPN, 2005, Cet. 2.

Sudarsono, Heri, Bank dan Lembaga Keuangan Syariah Deskripsi dan Ilustrasi, Yogyakarta: Ekonisia, 2003.

Sugiyono, Metode Penelitian Pendidikan Pendekatan Kuantitatif, Kualitatif, dan R\&D, Bandung: Alfabeta, 2007, Cet.7.

Suliyanto, Ekonometrika Terapan:Teori dan Aplikasi dengan SPSS, Yogyakarta: CV. ANDI OFFSET, 2016.

Sumber: Dokumen Bank Syariah Mandiri KCP Sangatta.

Sunyoto, Danang, Metodologi Penelitian Ekonomi: Alat Statistik \& Analisis Output Komputer, Yogyakarta: CAPS, 2011.

, Metodologi Penelitian Akuntansi, Bandung: PT. Refika Aditama, 2013, Cet.

Supranto, Pengukuran Tingkat Kepuasan Pelanggan, Jakarta: Rineka Cipta, 2001.

Tjiptono, Fandy, Strategi Pemasaran, Yogyakarta: Andi Offset, 2015.

Tungga, Ananta Wikrama, dkk., Metodologi Penelitian Bisnis, Yogyakarta: Graha Ilmu, 2014, Cet. 1. 